\title{
Shoreline changes in Concón and Algarrobo bays, central Chile, using an adjustment model
}

\author{
Carolina Martínez ${ }^{1}$ \\ ${ }^{1}$ Departamento de Geografía, Facultad de Arquitectura, Urbanismo y Geografía \\ Universidad de Concepción, Víctor Lamas No 1290, Barrio Universitario s/n, Concepción
}

\begin{abstract}
Adjustment models for both Algarrobo and Concón bays, central Chile, are presented herein; the results show a nearly logarithmic spiral shape for the shore. Spatial-temporal variations in the shorelines of both bays were found based on aerial photographs from different years. The results indicate important variations in the relative position of the Concón Bay shoreline between 1945 and 2006, with extreme oscillations (-368 to $123.8 \mathrm{~m}$ ) only occurring in the proximal zone, where the Aconcagua Estuary is located. On the other hand, the spatial-temporal variations in the Algarrobo Bay shoreline between 1967 and 2006 are moderate (131 in the proximal and -73 in the distal zone). Whereas Concón Bay exhibits a stable state of equilibrium for the past 60 years, if the estuary zone is excluded, Algarrobo Bay presents a stable state with a tendency for growth in the proximal zone and retreat in the distal zone. The results are discussed in terms of coastal changes associated with highly urbanized shorelines and applications for coastal area management that are derived from the models.
\end{abstract}

Key words: headland bay, embayment, shoreline, central Chile.

\section{Cambios en la línea litoral de las bahías de Algarrobo y Concón, Chile central, a través de un modelo de ajuste}

\begin{abstract}
RESUMEN. Se presentan los resultados de la aplicación de un modelo de ajuste para las bahías de Algarrobo y Concón en Chile central, cuya forma se aproxima a una espiral logarítmica. A partir del uso de fotografías aéreas correspondientes a diferentes años, se determinaron las variaciones espacio-temporales de la línea litoral en ambas bahías. Los resultados indican que la bahía de Concón ha presentado importantes variaciones en la posición relativa de su línea litoral para el período 1945 a 2006, únicamente en su zona proximal, lugar en donde se localiza el estuario Aconcagua con oscilaciones extremas entre - $368 \mathrm{~m}$ y 123,8 m. En la bahía de Algarrobo, las variaciones espacio-temporales de la línea litoral son de magnitud moderada para el período comprendido entre 1967 y 2006, presentando valores extremos de $131 \mathrm{~m}$ en la zona proximal y de $-73 \mathrm{~m}$ en la zona distal. Mientras que la bahía de Concón exhibe un estado de equilibrio estable para los últimos 60 años, si se excluye la zona estuarial, la bahía de Algarrobo para los últimos 35 años, presenta estabilidad con tendencia a la acreción en su zona proximal y al retroceso en su zona distal. Se discuten los resultados en relación con los cambios asociados a la línea litoral en zonas costeras fuertemente urbanizadas y las aplicaciones derivadas del uso de modelos para orientar el manejo de las áreas costeras.
\end{abstract}

Palabras clave: bahía en zeta, ensenada, línea litoral, Chile central

Corresponding author: Carolina Martínez (carolmartinez@udec.cl)

\section{INTRODUCTION}

Most coasts have curved bays and inlets and several authors have proposed different theoretical schemes for explaining these formations. At present, the curvatures are agreed to result from the interaction of geological-geomorphological and oceanographic factors such as the nature of the coast (structural characteristics, lithology, coastline orientation) and the dynamic characteristics of the nearshore (wave climate, refraction-diffraction processes induced by the submarine morphology) (Araya-Vergara, 1986; Carter, 1988; Komar, 1998; Short, 1999; Woodroffe, 2003). Because embayment curvatures often 
resemble segments of a logarithmic spiral, they are often referred to as logspiral bays, headland bays, and crenulate bays. Such bays tend to have sandy seaboards, with beaches that are known as headland bay, spiral, curved, and hooked beaches.

According to Phillips (1985), all marine and estuarine coasts have headland bay beaches. These are located on the leeward side of the headlands or engineered structures like docks or jetties.

A typical characteristic of headland bay beaches is the marked correspondence between shape and refraction pattern, as observed by Davis (1958, in Short, 1999), who concluded that the orientation and shape of these beaches are controlled by the refraction pattern of dominant waves (swells). Several numerical models support this proposal (Rea \& Komar, 1975; Le Blond, 1979).

One of the first and most common models for explaining and modeling headland bay development was presented by Yasso (1965); this model followed earlier work that applied circle arcs (Bruun, 1954) and cycliods (Hoyle \& King, 1958). Since the straightest and most exposed parts of the model tend not to adjust to the inlet and due to the difficulty in establishing the diffraction pole, Hsu et al. (1987, 1989), Hsu \& Evans (1989), and later Silvester \& Hsu (1993) developed a more universal relationship describing the beach shapes in headland bays through a parabolic shape and a static equilibrium (Short, 1999). Hsu et al. (1989) applied an empirical model to enclosed beaches, using field and laboratory data to relate the parameters that define the beach's shape; Tan \& Chiew (1994) later modified this model, assaying beaches in terms of their stable equilibrium conditions and highlighting the importance of obliqueness of the waves on the beach shape. Jiménez et al. (1994, in Sánchez-Arcilla \& Jiménez, 1994) applied both methods to Catalan beaches and found the former gave the best predictions for shape.

Some research has established than, for typical headland bay beaches, the wave energy distribution changes systematically along the coast that is affected by the headland, acting on the slope of the beach, which is contingent upon grain size (Phillips, 1985). According to observations by Bascom (1951), beach slope and the size of the sediment increase in the protected area behind the headland toward the more exposed part of the beach. This allowed Le Blond (1979) to determine that the true test of a logarithmic spiral model is to reproduce both the morphological and sedimentary characteristics of the inlet, as well as the crenulate platform, since the state of equilibrium of the headland bay is due to close ties between wave energy, beach slope, and grain size, which, in turn, guide the logarithmic spiral form.

The concepts of temporal and spatial scale, as well as that of equilibrium, have been fundamental aspects in adjustment model propositions. Several methods have been established to determine variability in the relative shoreline position (Silvester, 1960, 1970, 1974; Sonu, 1973; Ozasa, 1977; Crowell et al., 1991; Dolan et al., 1992; Fenster et al., 1993). Some consider the influence of variations in the average sea level over long periods (Blum et al., 2002; Van Goor et al., 2003) and the effect of storms on the coastline position (Fenster et al., 2001). Techniques for coastline identification and intertidal topography have been applied, especially in areas with important mobility or urbanization (Siegle et al., 2002; Turner et al., 2004). Recently, Dai et al. (2004) used logarithmic spiral curves and fractal analysis to study the equilibrium states of 34 inlets along the southern coast of China.

In Chile, such research and applications are still incipient as information on the coast is available only for specific sectors and lacks continuity. Important advances have been made in the field (Paskoff, 1970; Araya-Vergara, 1985, 1986, 1987, 1996; Castro \& Andrade, 1989; Andrade \& Castro, 1990; Martínez, 2001; Soto, 2005). Nonetheless, models aimed at learning about or explaining the evolution of coastal areas receive little attention, even though demographic and real-estate pressure make coastal cities priority areas.

The objective of this work is to apply an adjustment model to two bays in central Chile to facilitate interpretations of coastal evolution on middle-term time scales. The bays of Algarrobo and Concón are subjected to heavy urbanization and anthropogenic pressure due largely to residential and economic activities, especially tourism. Thus, the goal is to determine the state of equilibrium of the shoreline in order to be able to generate different applications associated with managing the coastal area.

\section{MATERIALS AND METHODS}

\section{Study area}

The bays of Algarrobo and Concón have nearly logarithmic spiral forms (Figs. 1 and 2). Concón Bay is the distal zone of the Valparaíso embayment (Fig. 

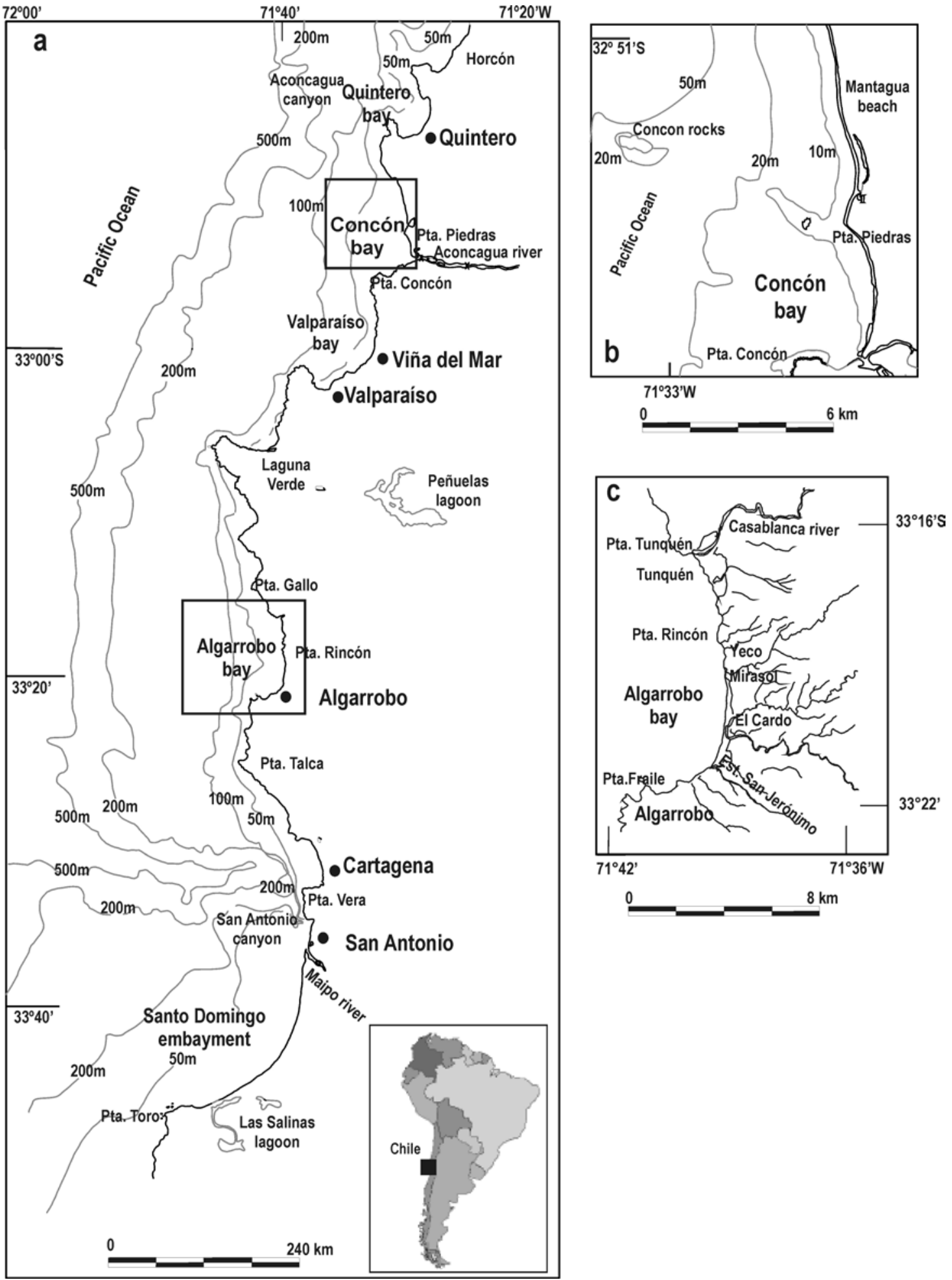

Figure 1. a) Location map of the study area, b) Concón bay, c) Algarrobo bay. 

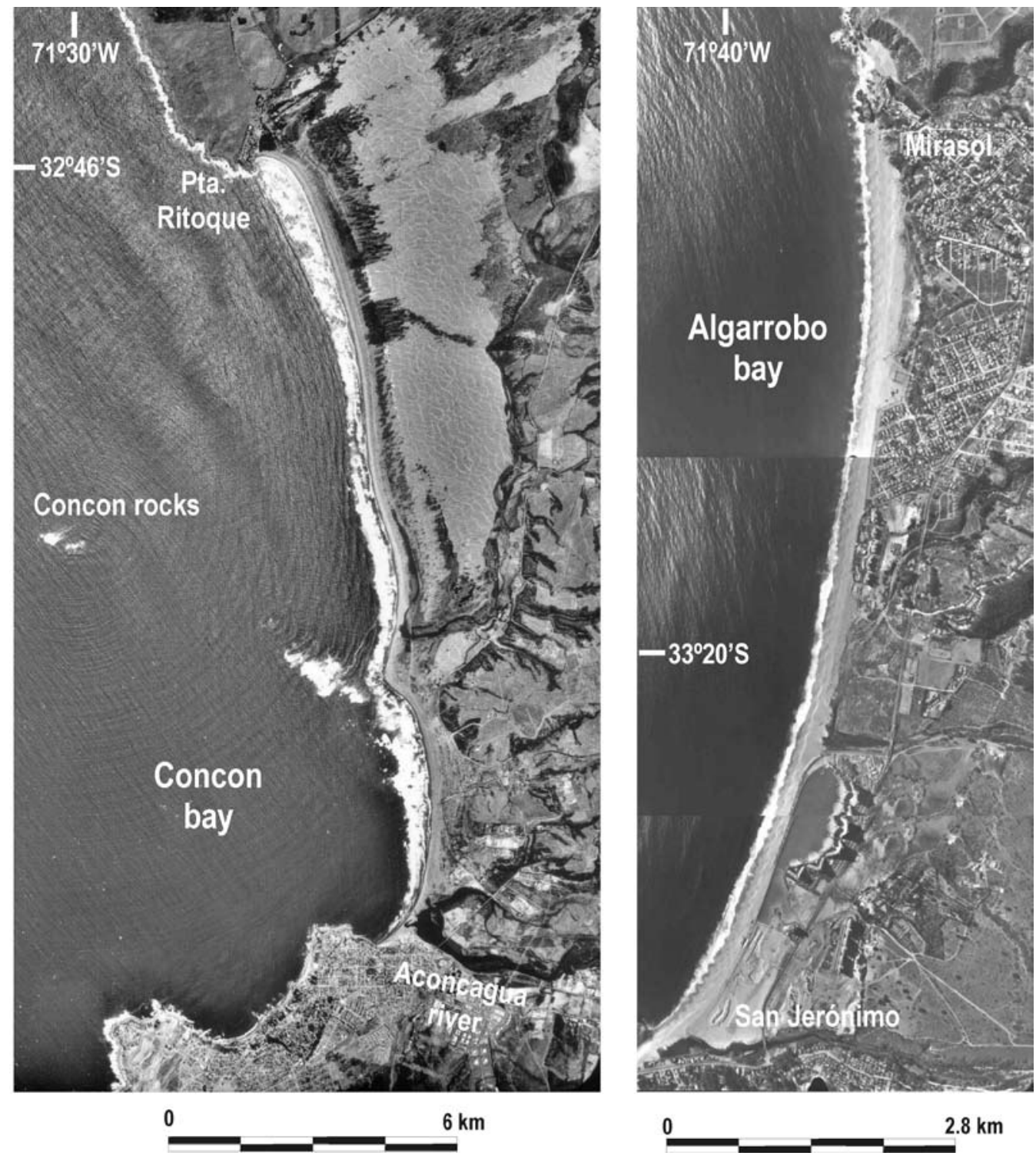

Figure 2. Concón and Algarrobo bays, central Chile.

1b). Both are open to the north and are delimited by two main rocky promontories: Ritoque Point (distal) and Concón Point (proximal) for Concón Bay $\left(32^{\circ} 49-32^{\circ} 55^{\prime} \mathrm{S}\right)$, and Tunquén Point (distal) and Fraile Point (proximal) for Algarrobo Bay ( $33^{\circ} 16^{\prime} 30$ $\left.33^{\circ} 22^{\prime} \mathrm{S}\right)$. The geology of the coast is constituted by a Paleozoic granodioritic complex (permian-carboniferous) investigated by Muñoz Cristi (1971). The shore consists of marine steps cut into the coastal batholite rocks and modeled by marine action. Block tectonics have influenced the configuration of this coast (Paskoff, 1970).
Algarrobo Bay is characterized by an extensive sandy seaboard in its central and proximal zones, with local sedimentary contributions through the estuaries El Membrillo and San Jerónimo and the gorge El Yugo (Fig. 1c). The central zone of the inlet contains Casablanca Estuary, which flows into the beach enclosed by Tunquén. The central and proximal zones of Algarrobo Bay are a high-energy reflective beach; its ample beach cusps associated with counter currents (Martínez, 2001). The distal zone (Tunquén beach) has a kind of intermediate transverse bar and rip beach. Both types of beach 
tend to be maintained over decadal temporal scales (Martínez, 2001).

The proximal zone of Concón Bay contains the Aconcagua River estuary system and the central and distal zones a sandy seaboard around $3 \mathrm{~km}$ long with ancient adjacent dunes (Fig. 2). It also has an ample, intermediate, transverse bar and rip surf zone according to the classification of Wright \& Short (1984) and Short (1999). The marine bottom is shallow, gradually reaching 15 to $16 \mathrm{~m}$ depth in the center of the bay.

In general, the area is affected by a nearly continuous swell effect (seabottom), originating in the WSW (SHOA, 1994). Some wave climate research in central Chile (Araya-Vergara, 1971; Fonseca, 1985; Martínez, 2001) has shown the more important and frequent wave directions to be $\mathrm{W}, \mathrm{SW}$, and NW, generally agreeing with the prevailing wind direction. Maximum wave heights are between 1.0 and $3.0 \mathrm{~m}$ (72\%); significant wave heights between 0.5 and $2.5 \mathrm{~m}(88 \%)$, and maximum wave heights by period between 8 and 12 s (75\%) (Martínez, 2001). The tidal regime is mixed, with semi-diurnal tendency and microtidal type.

\section{Procedures}

The study was based on historic cartographies consisting of aerial photographs from 61 years in the case of Concón Bay and 39 in the case of Algarrobo Bay. This was used to determine changes in the relative shoreline position over time. The cartographies were complemented with topographic data having geodetic connections resulting from recent field work (April 2001; September 2002, July 2004, March 2005, April 2006). In order to apply the adjustment model, the study area was limited to the segment of the embayment that most resembled a logarithmic spiral. In Concón Bay, this was the central and proximal zones between the rocky promontories of Piedras Point and Concón Point ( $\left.32^{\circ} 53-32^{\circ} 55^{\circ} \mathrm{S}\right)$ and, in Algarrobo Bay, the area between the rocky promontories of

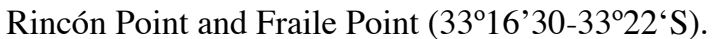

The shoreline was determined by identifying the high tide line in all the sources used (aerial photographs, field work). When combined, the notable points or common characteristics in all the photograms could be observed, providing the necessary geo-referencing checkpoints.

The geo-referencing process was done with ERDAS 8.0 software. A polynomial adjustment was made to each of the checkpoints provided by an RMS (root mean square) not greater than $1 \mathrm{~m}$ for each of the models; more than five checkpoints were used to assure a good distribution in the respective photograms. Geo-referenced aerial photos (geoTIFF) were generated using the export feature of the ERDAS software and the UTM coordinate system in geodetic datum WGS 84 .

All restitutions were taken to a scale of 1:20,000, which was the intermediate scale of the aerial photographs used and is the maximum enlargement possible for photograms at a scale of 1:70,000. This avoided the generation of distortions when marking the coastline due to the pixel resolution.

The geoTIFF images were imported into AUTODAC Land Development software for vectoring the coastline; a dxf file was generated for each vectored image. Next, the changes in the shoreline were quantified by superimposing each of dxf file over the plane of reference obtained by applying the adjustment model. Finally, each dxf file was exported to a shape (shp) format to visualize and quantify the changes in the coastline through the use of ARGIS 8.1 of ESRI.

The logarithmic spiral model applied was based on the works of Yasso (1965) and Le Blond (1979), and considered the examples presented in Komar (1998) and Short (1999) for bays that form a nearly logarithmic spiral. The model is based on the use of the polar equation of a logarithmic spiral of the form:

$$
\mathrm{R}=\mathrm{a} \exp (\Phi \operatorname{cotg} \mathrm{b})
$$

where $\mathrm{a}$ and $\mathrm{b}$ are constant values and $\Phi$ is the angle of the polar azimuth that varies between 0 and $360^{\circ}$ (Fig. 3).

A series of values applicable to each of the constants $(a, b)$ was tested, taking values for the angle $\Phi$. Finally, two values $(\mathrm{a}, \mathrm{b})$ were determined that established the best fit for the study area shoreline. In the case of Concón Bay, the values were 1.9 for the constant "a" and 0.7 for the constant "b"; these were then put into the equation. The graph adjusted with the equation coincided with the aerophotogrammetric restitution of the shoreline from 1996, so this adjustment was used as the reference level when quantitatively establishing spatial-temporal variations in the shoreline for the analyzed historical series. In the case of Algarrobo Bay, 1967 was the year with the best fit.

A systematic measuring criterion was used with 100 - $m$ intervals beginning at the far southern (proxi- 


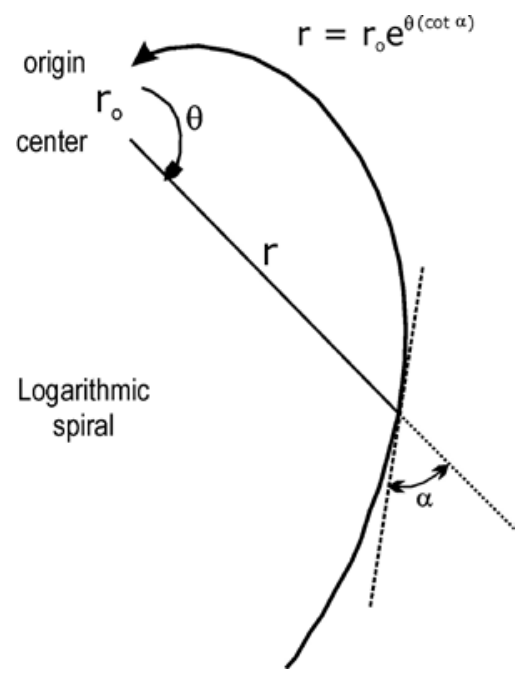

Figure 3. Spiral logarithmic model (Komar, 1998). mal) zone of the study area (Fig. 4). Three states were determined in the system according to Araya-Vergara (1985, 1986): advance (variations over $50 \mathrm{~m}$ ), stationary $(0-50 \mathrm{~m})$, and retreat (variations over $-50 \mathrm{~m}$ ) according to the adopted reference level.

\section{RESULTS}

The tendencies found when applying the logarithmic spiral adjustment model to Algarrobo and Concón bays are given in Table 1. In Concón Bay, a strong sedimentary dynamic was found in the proximal zone, in the area of the Aconcagua River estuary (Fig. 5). However, the central and distal zones were stable, with no significant variations in the analyzed series. The greatest changes were associated with
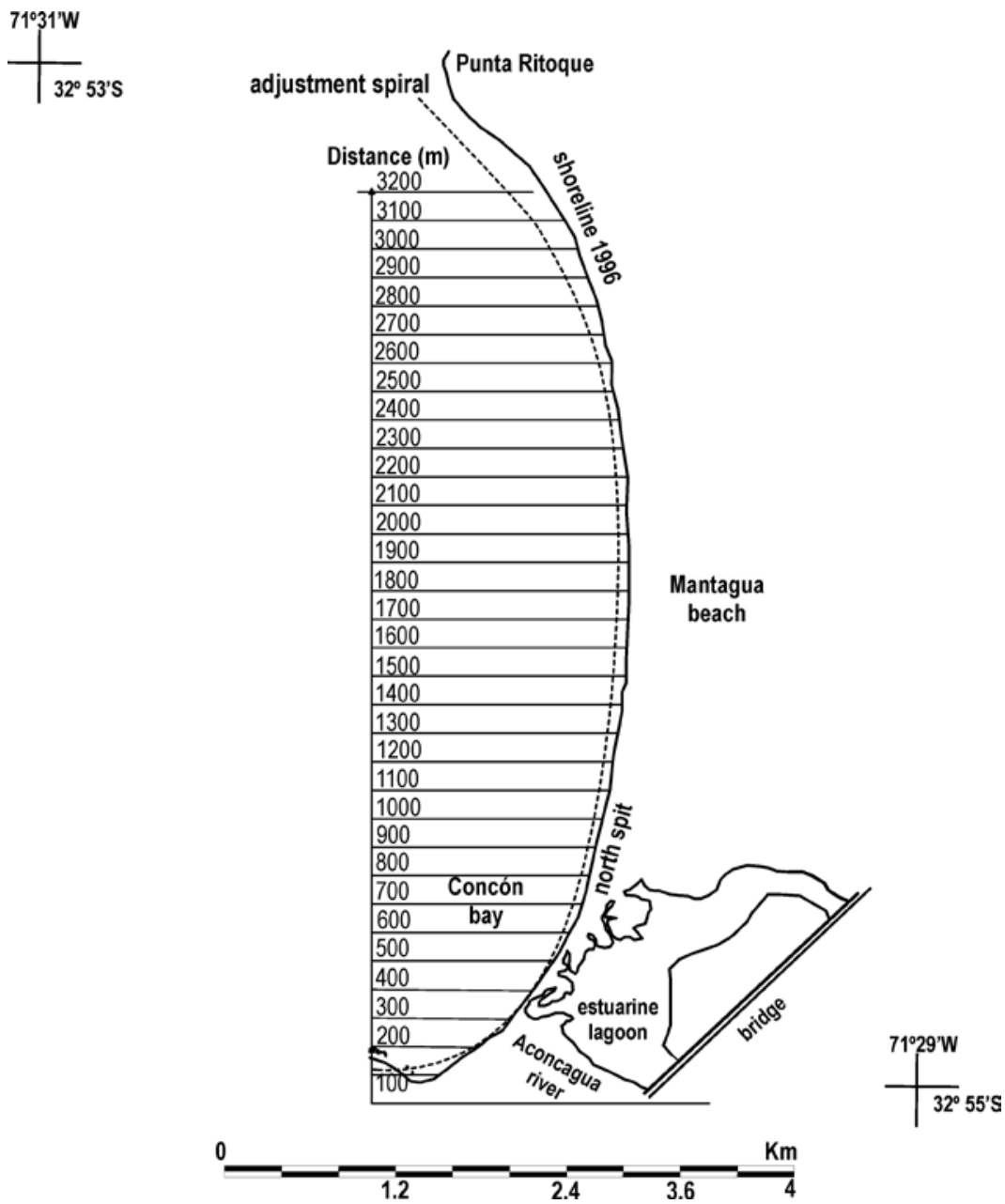

Figure 4. Adjustmen model applied to Concón bay. 
Table 1. Temporal-spatial variations of the Concón and Algarrobo bay shorelines (maximum and minimum ranges).

\begin{tabular}{|c|c|c|c|c|c|c|c|c|c|}
\hline \multicolumn{5}{|c|}{ Concón Bay $\left(r^{2}=0.22\right)$} & \multicolumn{5}{|c|}{ Algarrobo Bay $\left(r^{2}=0.92\right)$} \\
\hline Year & Advance & Position & Retreat & Position & Year & Advance & Position & Retreat & Position \\
\hline 1945 & 39 & Proximal & -80.21 & Average & 1980 & 130.89 & Proximal & -11.53 & Distal \\
\hline 1954 & 3.96 & Proximal & -73.31 & Average & 1996 & 139.89 & Proximal & - & - \\
\hline 1970 & - & - & -132.67 & Proximal & 2000 & 96.93 & Distal & -28.03 & Proximal \\
\hline 1972 & 32.94 & Distal & -73.15 & Proximal & 2006 & 71.67 & Proximal & -73.33 & Distal \\
\hline 1975 & 2 & Distal & -142.43 & Proximal & & & & & \\
\hline 1977 & 83.77 & Distal & -368.65 & Proximal & & & & & \\
\hline 1980 & 0 & Distal & -226.02 & Proximal & & & & & \\
\hline 1993 & 13.22 & Distal & -208.77 & Proximal & & & & & \\
\hline 1994 & 36.77 & Proximal & -53 & Proximal & & & & & \\
\hline 2001 & 0 & Proximal & -123.75 & Proximal & & & & & \\
\hline 2004 & 123.8 & Proximal & -23.79 & Distal & & & & & \\
\hline 2005 & 40.41 & Proximal & -117.9 & Proximal & & & & & \\
\hline \multicolumn{2}{|c|}{ Series Average } & & \multicolumn{2}{|l|}{$-30.26 \mathrm{~m}$} & \multicolumn{2}{|c|}{ Series Average } & & $+25.52 \mathrm{~m}$ & \\
\hline
\end{tabular}

states of retreat that reached values of up to $-368 \mathrm{~m}$ (1977) in the area of the Aconcagua Estuary coastal spits. Likewise, the only significant value in the series associated with a state of advance (over $50 \mathrm{~m}$ ) was located in the bay's proximal zone; a maximum of $+123.8 \mathrm{~m}$ was recorded in the area of the north coast spits. The values tended to be more stationary in the direction of the distal zone. The main changes in the relative shoreline position were recorded in the area influenced by the Aconcagua Estuary.

Seasonally, the maximum values were associated with states of retreat in the winter (-226 m, June 1980) and the transitional (autumn, spring) months; a very slight tendency toward advance was observed in summer (+123 m, February 2004).

Changes of an intermediate magnitude were seen in the relative position of the Algarrobo Bay coastline in the proximal and distal zones of the analyzed series (Fig. 6). The main changes were recorded in the proximal zone (advance) with extreme values of +130 m (1980) and +139 m (1996). Representative values of retreat states were not very significant, and the only value recorded was for $2006(-73 \mathrm{~m})$ in the bay's distal zone.

Seasonally, the advance processes affected especially the proximal zone in winter $(+130 \mathrm{~m}$, June $1980 ;+139 \mathrm{~m}$, August 1996) and the distal zone in transitional periods (+96 m, March 2000).
The degree of association found between the state of the shoreline and its relative position according to the year considered was high for Algarrobo Bay (peak $r=-0.96$ ) and low for Concón Bay (peak $r=0.75$ ). This was so even when the behavior of Algarrobo Bay differed from the general tendency of proximal advance and distal retreat in 2000 (Table 2).

Figures 7 and 8 offer a spatial representation of the changes in the relative position of the coastline, indicating the extreme values for its position in the bay found in the historical series. Thus, it can be seen that the maximum values obtained in Concón Bay (Fig. 7) were concentrated in the proximal zone (Aconcagua Estuary), with a strong tendency to retreat, which decreased progressively toward the central and distal zones, where the values were significantly lower and within the stable range.

In Algarrobo Bay, the maximum values were located both in the proximal and distal zones (Fig. 8), whereas the central zone was stable. Unlike Concón Bay, this system tended toward a state of advance.

\section{DISCUSSION}

When interpreting the results derived from the application of the logarithmic spiral adjustment model, two essential aspects should be considered. First is the problem of the scale of representation. Scales of 


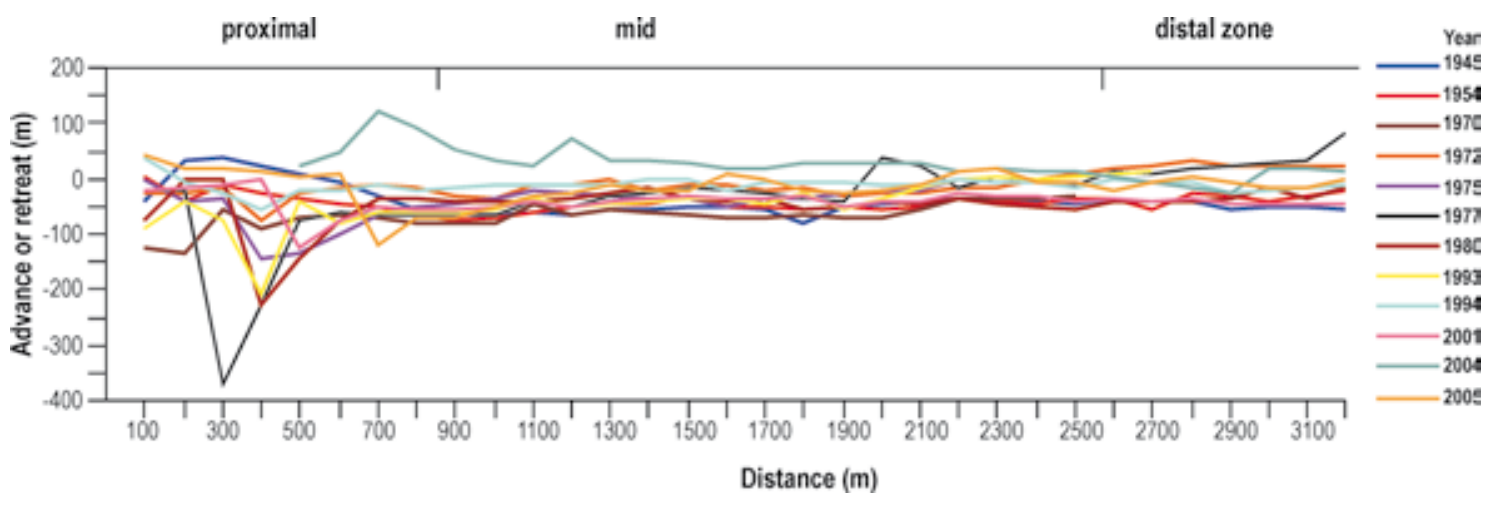

Figure 5. Relative position variations of shoreline, Concón bay.

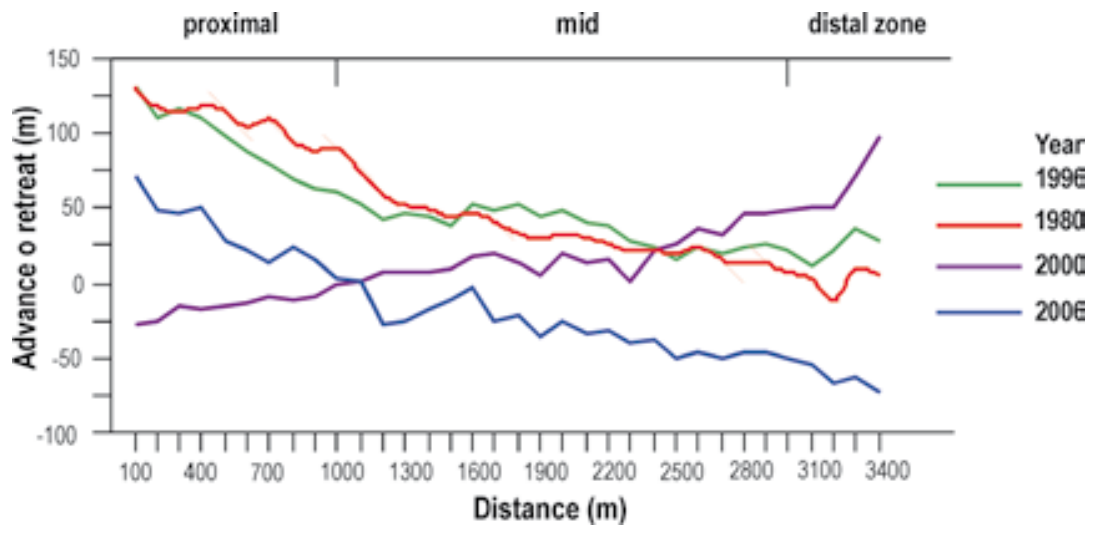

Figure 6. Relative position variations of shoreline, Algarrobo bay.

Table 2. Linear regressions (r) between position and variations of the shore line for Concón and Algarrobo bays.

\begin{tabular}{cccccc}
\hline \multicolumn{3}{c}{ Concón Bay (r) } & \multicolumn{3}{c}{ Algarrobo Bay (r) } \\
\hline 1945 & -0.47 & 1980 & 0.31 & 1980 & -0.96 \\
1954 & 0.01 & 1993 & 0.73 & 1996 & -0.89 \\
1970 & 0.71 & 1994 & 0.06 & 2000 & 0.93 \\
1972 & 0.75 & 2001 & 0.05 & 2006 & -0.95 \\
1975 & 0.51 & 2004 & -0.70 & & \\
1977 & 0.66 & 2005 & 0.06 & & \\
\hline
\end{tabular}




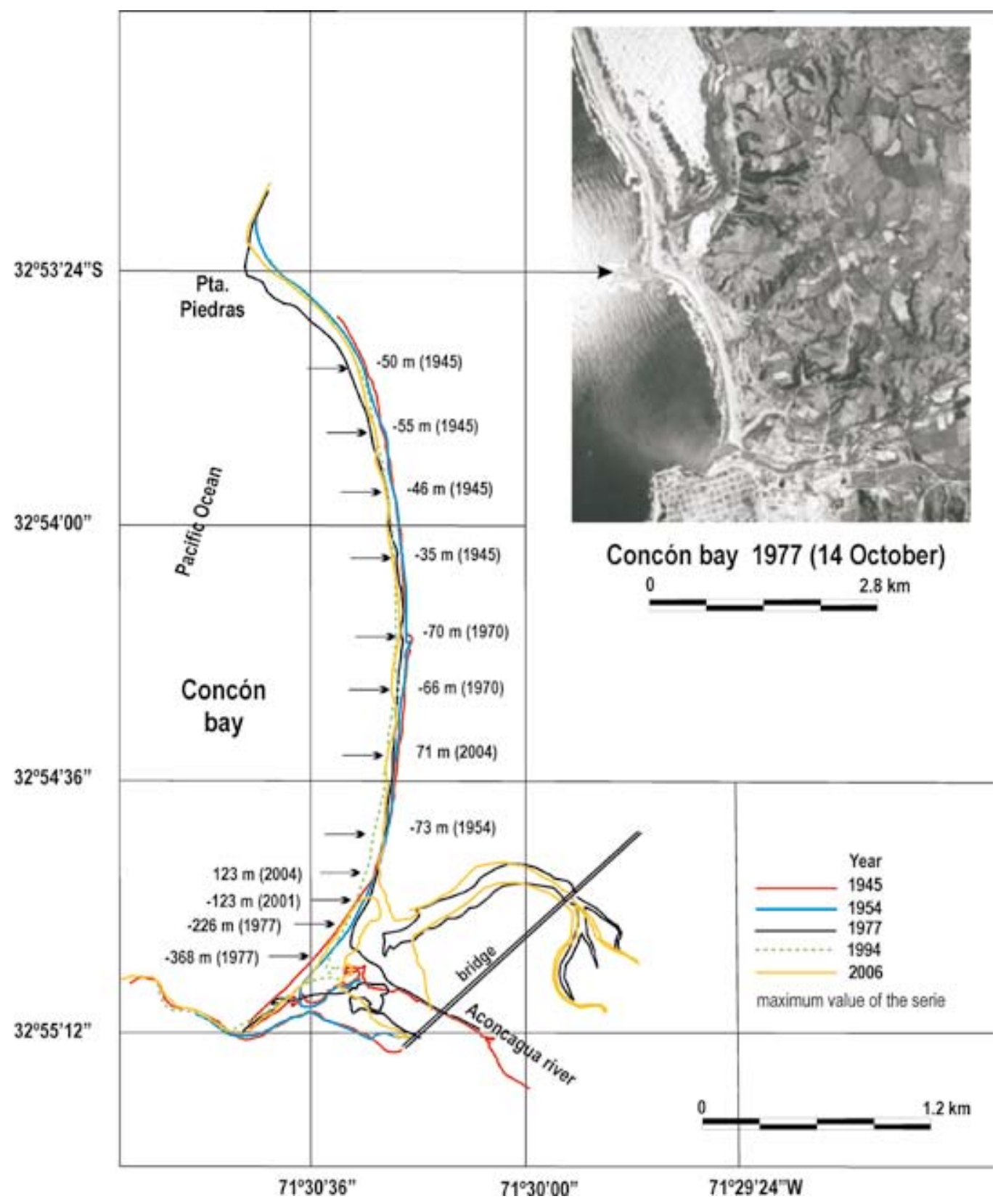

Figure 7. Relative position variations of shoreline, Concón Bay (1945-2006).

different spatial resolution were used, varying from $1: 8,000$ to $1: 70,000$. Aerophotogrammetrically, it is not convenient to use a very wide range of scales due to the accumulative errors that are generated when passing the state of the coastline to an intermediate scale performance plane. In this initial experiment, $70 \%$ of the working scales for Concón Bay were between 1:8,000 and 1:25,000; the remaining 30\% consisted of smaller scales (greater than 1:30,000).
For Algarrobo Bay, $50 \%$ of the scales were between $1: 8,000$ and $1: 14,000$ and the other half were between 1:20,000 and 1:70,000. The ideal methodological procedure requires converting the smaller working scales to a range of 1:20,000; this is the recommended limit from the aerophotogrammetrical point of view, as it avoids transferring errors to the representation plane, which, in the case of the analyzed bays was done at a scale of 1:20,000. Second is the problem of 


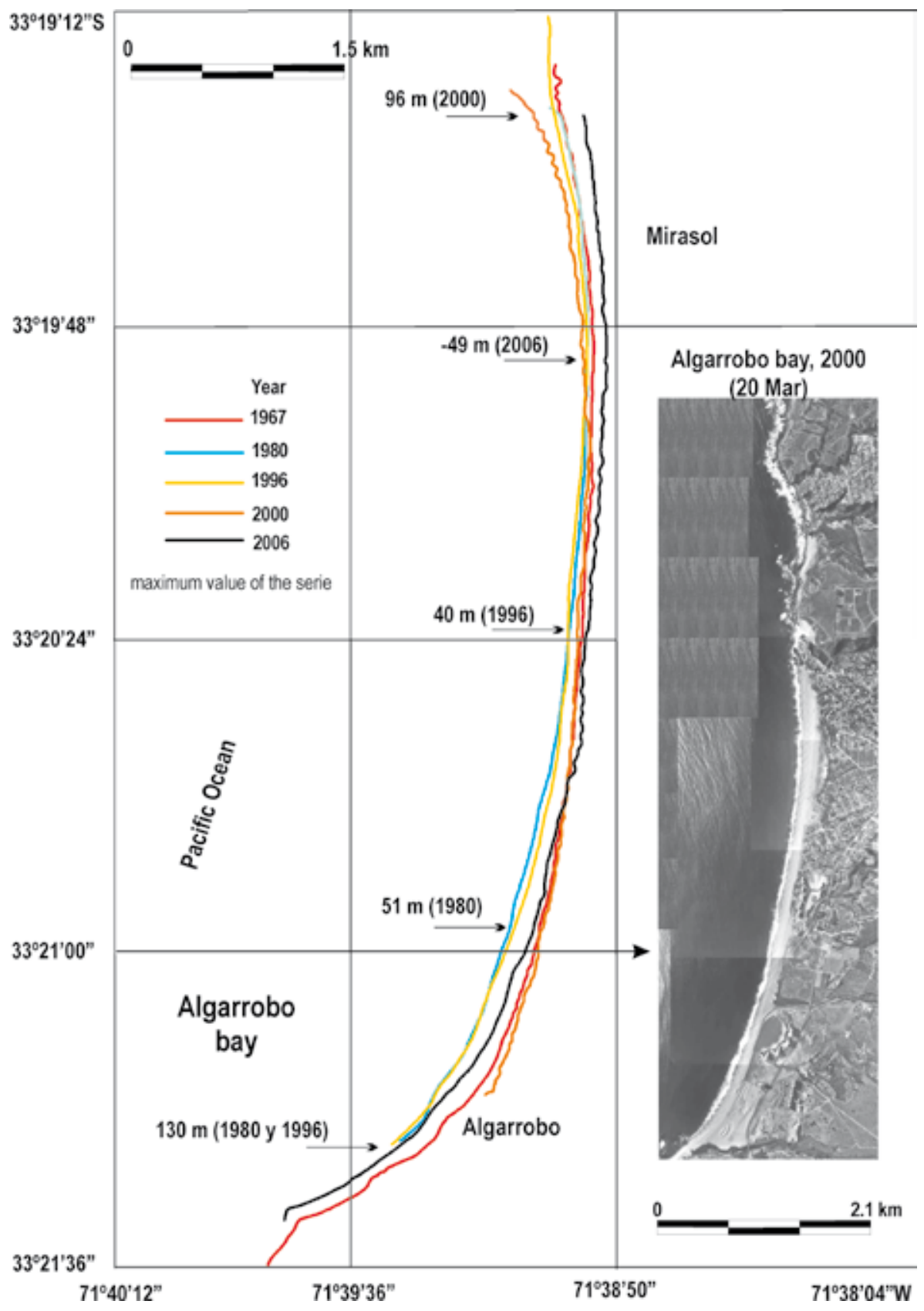

Figure 8. Relative position variations of shoreline, Algarrobo Bay (1967-2006).

the historic series of photograms. In this is a statistical series of shoreline states, morphodynamics are a function of variables that have differential spatial and temporal behavior, that is, temporal scales for which seasonality is relevant; moreover, effects induced by non-periodic events such as rough waters should be also considered. The aerial photographs of Concón Bay were taken in summer (33.3\%), winter (11.1\%), and in transitional seasons (autumn, spring; 55.5\%). For Algarrobo Bay, $75 \%$ of the aerial photographs corresponded to winter and $25 \%$ to transitional periods; no data were obtained for summer. Given the differences in the quality of the series constructed (13 cases for Concón Bay and five for Algarrobo Bay), the two systems were not comparable; this can also explain the difference in the average tendencies of 
the series: $-30.26 \mathrm{~m}$ for Concón Bay and $+25.5 \mathrm{~m}$ for Algarrobo Bay.

Historical series should be constructed in order to contrast aspects of these bays considering both seasonal and spatial differentiation in terms of the shoreline adjustments based on representative seasonal conditions.

With the logarithmic spiral adjustment model, it is difficult to establish unequivocally the location of the diffraction pole that gives rise to the $\theta$ angle and that leads to the simulation of the logarithmic spiral form. In the analyzed cases, this point was located directly using the aerial photograph that provided the best fit of the series (1996 for Concón and 1967 for Algarrobo).

However, diffraction varies from one inlet to another and is a process that should be determined instrumentally to avoid errors induced by the model. In response to this, the main criticism of the model, Hsu \& Evans (1989) proposed the parabolic function for bays in equilibrium based on arguments laid out by Hsu et al. (1987). These authors indicated that, when the origin of the logarithmic spiral coincides with the control point, it fits well to the maximum curvature of the inlet but deviates from its straight part. Later, Moreno \& Kraus (1999) proposed the hyperbolic tangential function that they applied to 46 beaches in Spain and North America; this function does not require establishing a point of diffraction since it fixes points in the headland that act as fixed control points and the equation values can be calculated to obtain the minimum RMS for a better fit of the curve (Benedet et al., 2004).

Different results have been obtained when applying adjustment models to explain the evolution of the coastline. Similar adjustments were done for the resort beach Camboriú along Brazil's Santa Catarina coast (Benedet et al., 2004). Along the Río Grande Do Sul coast, also in Brazil, important processes of erosion, principally induced by anthropogenic activity, have been recognized (Slomp et al., 2002). Along the Spanish mesotidal coast of Huelva, made up of an extensive sandy and rocky seaboard over headland bays, the effects of the coastal erosion processes have been quantified for the 1971-2001 period with aerophotogrammetric mapping and geodetic techniques (Del Río et al., 2002). Several causes of erosion were found: in the short term, recent coastal infrastructure due to tourist activities (construction of docks, jetties, marinas); in the medium term, reservoirs and dams installed in the upper courses of the source rivers that supply sediment to maintain the coastal mass balance, and, in the long term, sea level variations that are estimated to equal the effects of non-periodical storm events.

In Chile, the responses of inlets to states of advance was considered in morphogenetic research by Araya-Vergara (1985, 1986, 1987, 1996), who established that, along the central coast, beach orientation and kind of emplacement are fundamental variables in the transportation of mass and energy.

This is reflected in the types of forms present on the sandy seaboard (presence or absence of dune masses), aspects also characterized by Martínez (2001) and Soto (2005) for short and medium term scales in large inlets of central Chile. In these areas, patterns of change were found to be associated with the morphodynamic states of the reef zone. If this is so, Algarrobo Bay should be more stable than Valparaíso Bay because the former is reflective and has high-energy (Martínez, 2001) and the latter is intermediate. Theoretically, reflective beaches are more stable than intermediate or dissipative beaches (Short, 1999). However, these studies are limited by scant systematization of field data, thereby hindering analyses of the transversal mass (cross-shore) equilibrium in the short and medium terms through variations in beach profiles. At any rate, the morphodynamic state of the reef zone and the kind of beach, according to Short (1999), seem to be good indicators of shoreline stability or at least should be correlated to this.

Thus, need to determine what kind of equilibrium characterizes the evolution of stability - and the factors affect this evolution - along the Chilean coast is evident. Almost the $70 \%$ of the beaches in the world experience erosion, generally on scales that do not surpass $1 \mathrm{~m}$ per year. This is significant if we consider that most beaches are no more than a few meters wide and the causes of this retreat are due to a combination of factors such as fluctuations in the average sea level, storm events, or human activities (Leatherman et al., 2000, in Muller et al., 2006).

For central Chile, Araya-Vergara (1985, 1986) reported that the coast, in spite of being in a state of equilibrium, presents a strong tendency to retreat, especially in the most curved zones of the bays that resemble segments of a logarithmic spiral. This further indicates that the characteristic patterns of change can be associated with the kind of coastline and its orientation.

The results presented herein coincide in the evalu- 
ation of stable states for the two systems analyzed and for the temporal scale used, although the tendency toward a state of retreat could not be observed. However, the degree of association between the relative position of the coastline and the values of change are notable in the case of Algarrobo Bay, where a high inverse correlation was found (maximum value of -0.96) for all the years analyzed except 2000, which was positive. This indicates that, in the direction of the bay's distal zone, the position of the coastline oscillates towards the advance-retreat states. It would be highly interesting to analyze whether these fluctuations are short term behaviors or obey the phenomenon of beach rotation reported for other beaches around the world (Short, 1999), which is closely tied to seasonal conditions.

No studies exist regarding the average sea level as a factor for explaining the variations found in this study area. However, the monthly averages (August 1980 to February 2001) of Valparaíso's tidal seasons (Martínez, 2001) show no important variations, with the exception of certain years that can be correlated with ENSO (El Niño Southern Oscillation) events. The monthly average obtained for the series was $0.70 \mathrm{~m}$, whereas the extreme values fluctuated between $0.948 \mathrm{~m}$ (May 1997) and $1.004 \mathrm{~m}$ (Dec. 1997), and between $0.54 \mathrm{~m}$ (Oct. 1983) and 0.567 m (Nov. 1983).

Recently, Encinas et al. (2006) discovered a Holocenic marine layer in Algarrobo (proximal zone) located $3.8 \mathrm{~m}$ above the average sea level, next to the San Jerónimo Estuary; this is associated with a shallow and transitional marine environment, in a relatively arid, warm climate. The $\mathrm{C}^{14}$ dating of this deposit provided an age of 6450 cal yr BP (calendar years before the present). Even though the temporal scales are not comparable, the role of block tectonics (uplifted or subsided blocks) in the configuration of Chile's coastal morphology is relevant; the maximum Holocenic transgression was established by Leonard \& Wehmiller (1991) for Caleta Michilla, Coquimbo Bay (7635 cal yr BP), and by Ota \& Paskoff (1993) for Tongoy Bay (7325 cal yr BP). This line of work on coastal evolution has not yet been explored in national research. Knowledge of the main characteristics of shoreline evolution on different spatial-temporal scales would allow improvements in the forecasting of related processes, especially along the Chilean coast where block tectonics have altered the levels reached by the sea, unlike the passive boundaries where the response to coastal evolution is centered on eustatic or glacio-eustatic readjustments.

\section{CONCLUSIONS}

1. Concón Bay is in a stable state of equilibrium, with important sedimentary dynamics in the south (proximal zone) associated with the Aconcagua River estuary. The area of direct estuarine influence, according to the results obtained herein, extends to the first $1,000 \mathrm{~m}$ to the north, where the greatest mobility of the coastline is detected. Beyond this threshold, the mobility of the coastline is in short supply, with a strong tendency to remain in a stationary state.

2. Algarrobo Bay is in a stationary state tending towards advance in its proximal zone and with a slight tendency to retreat in its distal zone.

3. The logarithmic spiral adjustment models enable a close approximation to the functioning of large inlets such as those found in Chile. The results should be contrasted with new experiments integrating other functions (parabolic, hyperbolic) or modeling methodologies (fractal analysis) that allow improved interpretations of coastal evolution considering different spatial and temporal scales.

\section{REFERENCIAS}

Andrade, B. \& C. Castro. 1990. La carta fisiográfica del litoral entre Tunquén y Santo Domingo (36 $16^{\circ}$ $33^{\circ} 38^{\prime}$ 'S). Rev. Geogr. Chil. Terra Australis, 32: 153-164.

Araya-Vergara, J.F. 1971. Determinación preliminar de las características del oleaje en Chile Central. Not. Mens. Mus. Nac. Hist. Nat., Santiago Chile, 15(174): 8-12.

Araya-Vergara, J.F. 1985. Trend analysis of shoreline changes and coastal management in Central Chile (33-34.5 $\left.{ }^{\circ} \mathrm{S}\right)$. In: Actes Excursion-Symposium $\mathrm{N}^{\circ}$ 9: La Côte Atlantique. Union Géographique Internationale. Commission sur l' Environnement Côtier, France, pp. 99-110.

Araya-Vergara, J.F. 1986. Cambios actuales de la línea litoral en Chile central sur. Rev. Geogr. Chil. Terra Australis, 29: 23-28.

Araya-Vergara, J.F. 1987. The evolution of modern coastal dune systems in Central Chile. In: V. Gardiner (ed.). International Geomorphology 1986 Part II. J.Wiley \& Sons, Chichester, pp. 1231-1239.

Araya-Vergara, J.F. 1996. Sistema de interacción oleaje-playa frente a los ergs de Chanco y Arauco, Chile. Gayana Oceanol., 4(2): 159-167.

Bascom, W. 1951. The relationship between sand size 
and beach face slope. Trans. Amer. Geophys. Union, 32: 866-874.

Benedet, L., A. Klein \& J. Hsu. 2004. Practical insights and aplicability of empirical bay shape equations. Notas RACIMAR, UNIVALI, 1-13.

Blum, M., A. Carter, T. Zayac \& R. Goble. 2002. Middle Holocene sea-level and evolution of the Gulf of Mexico coast (USA). J. Coast. Res., Special Issue, 36: 65-80.

Bruun, P. 1954. Coast erosion and the development of beaches profiles. Beach Erosion Board, Technical Memo, 44: 79 pp.

Carter, R. 1988. Coastal environments. Academic Press, London, 617 pp.

Castro, C. \& B. Andrade. 1989. Estado de morfoconservación del litoral entre Tunquén y Santo Domingo. Rev. Geogr. Norte Grande, 16: 51-56.

Crowell, M., S. Leatherman \& M. Buckley. 1991. Historical shoreline change: error analysis and mapping accuracy. J. Coast. Res., 7(3): 839-852.

Davis, R.A. 1997. The evolving coast. Scientific American Library, New York, 233 pp.

Dai, Z., C. Li \& Q. Zhang. 2004. Fractal analysis of shoreline patterns for crenulate-bay beaches, Southern China. Estuar. Coast. Shelf Sci., 61: 65-71.

Del Río, L., J. Benavente, F. Gracia, G. Infuso, J. Martínez-del-Pozo, L. Domínguez, A. RodríguezRamírez, E. Flores, L. Cáceres, F. López-Aguayo \& J. Rodríguez-Vidal. 2002. The Quantification of coastal erosion processes in the South Atlantic Spanish coast: methodology and preliminary results. Littoral 2002, The Changing Coast. EUROCOAST/ EUCC, Porto-Portugal Ed. EUROCOAST-Portugal, pp. 383-390.

Dolan, R., M. Fenster \& S. Holme. 1992. Spatial analysis of shoreline recession and accretion. J. Coast. Res., 8(2): 263-285.

Encinas, A., F. Hervé, R. Villa Martínez, S. Nielsen, K. Finger \& D. Petersen. 2006. Finding of a Holocene marine layer in Algarrobo (33'22'S), central Chile. Implications for coastal uplift. Rev. Geol. Chil., 33(2): 339-345.

Fenster, M., R. Dolan \& J. Elder. 1993. A new method for predicting shoreline positions from historical data. J. Coast. Res., 9 (1): 147-171.

Fenster, M., R. Dolan \& R. Morton. 2001. Coastal storm and shoreline change. Signal or noise? J. Coast. Res., 17(3): 714-720.

Fonseca, T. 1985. Observaciones sobre los temporales que afectaron la bahía de Valparaíso en julio de 1984. Rev. Geog. Valparaíso, 16: 31-46.
Hoyle, J. \& G. King. 1958. The origin and stability of beaches. Proceedings $6^{\text {th }}$ International Conference on Coastal Engineering. ASCE, pp. 281-301.

Hsu, J., R. Silvester \& Y. Xia. 1987. New characteristics of equilibrium shaped bays. Proceedings $8^{\text {th }}$ International Conference on Coastal Engineering. ASCE, 140-144.

Hsu, J. \& C. Evans. 1989. Parabolic bay shapes and applications. Proc. Inst. Civil Eng., 87: 557-570.

Hsu, J., R. Silvester \& Y. Xia. 1989. Applications of headland control. J. Waterw. Port Coast. C-ASCE, 115(3): 299-310.

Komar, P. 1998. Beach processes and sedimentation. Prentice Hall, New Jersey, 544 pp.

LeBlond, P. 1979. An explanation of the logarithmic spiral plan shape of headland-bay beaches. J. Sediment. Petrol. 49(4): 1093-1100.

Leonard, E. \& J. Wehmiller. 1991. Low uplift rates and terrace reoccupation inferred from mollusc aminostratigraphy, Coquimbo bay, Chile. Quaternary Res., 38: 246-259.

Martínez, C. 2001. El efecto de ensenada en los procesos litorales de las ensenadas de Valparaíso, Algarrobo y Cartagena, Chile Central. Tesis de Magíster en Geografía. Escuela de Post Grado, Universidad de Chile, Santiago, 152 pp.

Moreno, L. \& N. Kraus. 1999. Equilibrium shape of headland-bay beaches for engineering design. Proceedings Coastal Sediments '99. ASCE, 1: 860-875.

Muller, J., R. Wust \& J. Hearty. 2006. Sediment transport along an artificial shoreline: "The Strand". Townsville, NE-Queensland, Australia. Estuar. Coast. Shelf Sci., 66: 204-210.

Muñoz Cristi, J. 1971. Estudios petrográficos y petrológicos sobre el batolito de la costa de las provincias de Santiago y Valparaíso. Ediciones Universitarias, Santiago, 93 pp.

Ota, Y. \& F. Paskoff. 1993. Holocene deposits on the coast of the north-central Chile: radiocarbon ages and implications for coastal changes. Rev. Geol. Chil., 20: 25-32.

Ozasa, H. 1977. The recent change of sandy shoreline in Japan. Komazawa Geogr., 20: 69-81.

Paskoff, R. 1970. Le Chili semi-aride. Bordeaux, Francia, 420 pp.

Phillips, D. 1985. Headland-bay beaches reviseted: an example from Sandy Hook, New Jersey. Mar. Geol., 65: 21-34.

Rea, C. \& P. Komar. 1975. Computer simulation mod- 
els of a hooked beaches shoreline configuration. J. Sediment. Petrol., 45: 866-872.

Sánchez-Arcilla, A. \& J. Jiménez. 1994. Ingeniería de playas (I): conceptos de morfología costera. Rev. Ingen. Agua, 2(1): 97-114.

Servicio Hidrográfico y Oceanográfico de la Armada de Chile. 1994. Anuario Hidrográfico de la Armada de Chile. Servicio Hidrográfico y Oceanográfico de la Armada de Chile, 46: 23-34.

Short, A.D. 1999. Handbook of beach and shoreface morphodinamics. John Wiley \& Sons, Chichester, $379 \mathrm{pp}$.

Siegle, E., D. Huntley \& M. Davidson. 2002. Modelling water surface topography at a complex inlet system-Teignmouth, UK. J. Coast. Res., (ICS 2002 Proceedings), 36: 675-685.

Silvester, R. 1960. Stabilization of sedimentary coastlines. Nature, 188: 467 pp.

Silvester, R. 1970. Growth of crenulated shaped bays to equilibrium. J. Waterw. Harb. Div., 96: 275-287.

Silvester, R. 1974. Coastal engineering. Vol II. Elsevier, Amsterdam, 338 pp.

Silvester, R. \& J. Hsu. 1993. Coastal stabilization, innovative concepts. Prentice Hall, New Jersey, $578 \mathrm{pp}$.

Slomp, L., E. Toldo, S. Dillenburg \& L. Tomazelli. 2002. Long- and short-term coastal erosion in
Southern Brazil. J. Coast. Res., Special Issue, 36: 273-282.

Sonu, C. 1973. Three dimensional beach changes. J. Geol., 81: 42-64.

Soto, M. 2005. Aspectos morfodinámicos de ensenadas desalineadas del litoral de Chile central. Pichilemu y Caleta Los Piures. Rev. Geogr. Norte Grande, 33: 73-87.

Tan, S. \& Y. Chiew. 1994. Analysis of bayed beaches in static equilibrium. J. Waterw. Port. Coast. C-ASCE, 120( 2): 145-153.

Turner, I., S. Aarninkhoft, T. Dronkerst \& J. Graths. 2004. CZM Applications of argus coastal imaging at the Gold Coast, Australia. J. Coast. Res., 20(3): 739-752.

Van Goor, M., T. Zitman, Z. Wang \& M. Stive. 2003. Impact of sea-level rise on the morphological equilibrium state of tidal inlets. Mar. Geol., 339: 1-17.

Woodroffe, C. 2003. Coasts: form process and evolution. Cambridge University Press, Cambridge, $623 \mathrm{pp}$.

Wright, L.D. \& A.D. Short. 1984. Morphodynamic variability of surf zones and beaches: a synthesis. Mar. Geol., 56: 93-118.

Yasso, W. 1965. Plan geometry of hedland-bay beaches. J. Geol., 73: 702-714. 